\title{
Protestant Ethics-In-Action
}

\section{The Emergence of Voluntary Social Work in Copenhagen 1865-1915}

\author{
Sevelsted, Anders
}

Document Version

Accepted author manuscript

Published in:

European Journal of Sociology / Archives Europeennes de Sociologie

DOI:

$10.1017 / \mathrm{S} 0003975618000073$

Publication date:

2018

License

CC BY-NC-ND

Citation for published version (APA):

Sevelsted, A. (2018). Protestant Ethics-In-Action: The Emergence of Voluntary Social Work in Copenhagen 1865-1915. European Journal of Sociology / Archives Europeennes de Sociologie, 59(1), 121-149. https://doi.org/10.1017/S0003975618000073

Link to publication in CBS Research Portal

\section{General rights}

Copyright and moral rights for the publications made accessible in the public portal are retained by the authors and/or other copyright owners and it is a condition of accessing publications that users recognise and abide by the legal requirements associated with these rights.

Take down policy

If you believe that this document breaches copyright please contact us (research.lib@cbs.dk) providing details, and we will remove access to the work immediately and investigate your claim. 


\section{Protestant Ethics-In-Action: The Emergence of Voluntary Social Work in Copenhagen 1865-1915}

\section{Anders Sevelsted}

Journal article (Accepted manuscript*)

\section{Please cite this article as:}

Sevelsted, A. (2018). Protestant Ethics-In-Action: The Emergence of Voluntary Social Work in Copenhagen 1865-1915. European Journal of Sociology / Archives Europeennes de Sociologie, 59(1), 121-149. 00I:

\section{$10.1017 / 80003975618000073$}

This article has been published in a revised form in European Journal of Sociology http://dx.doi.org/10.1017/S0003975618000073.

This version is published under a Creative Commons CC-BY-NC-ND. No commercial re-distribution or re-use allowed. Derivative works cannot be distributed. () European Journal of Sociology २०18

* This version of the article has been accepted for publication and undergone full peer review but has not been through the copyediting, typesetting, pagination and proofreading process, which may lead to differences between this version and the publisher's final version AKA Version of Record. 
Protestant Ethics-In-Action

Published in European Journal of Sociology

Protestant ethics-in-action: The emergence of voluntary social work in Copenhagen $1865-1915$

\section{Abstract}

This article shows how voluntary social work in late $19^{\text {th }} /$ early $20^{\text {th }}$ century Copenhagen emerged as the result of several creative re-interpretations of the cultural schemas of revivalist Protestantism as urban revivalists faced the social question. Informed by pragmatist cultural sociology, the concept of 'collective soteriology' is introduced as a way of analyzing the Protestant reinterpretations in terms of doctrine, ideals of community, and recipes for action. It is shown how Lutheran revivalist ideas at the same time encouraged, constrained, and shaped the voluntary social action undertaken. The paper aims to uncover a sociologically neglected European tradition of civic action, to contribute to the sociology of Protestantism's influence on civil society, and to develop a theoretical framework for analyzing the role of ideas in non-contentious collective action.

KEYWORDS: Protestantism, Voluntarism, Social work, Civil society, Welfare

This is the accepted version of the following article: Sevelsted, Anders (2018). "Protestant EthicsIn-Action: The Emergence of Voluntary Social Work in Copenhagen 1865-1915." European Journal of Sociology 59(1): 121-149, which has been published in final form at DOI:

$10.1017 /$ S0003975618000073.

The final version is available at the following address:

https://doi.org/10.1017/S0003975618000073 
Protestant Ethics-In-Action

Published in European Journal of Sociology

\section{Introduction}

During the fifty-year period spanning from ca. 1865 to ca. 1915, the Danish capital of Copenhagen saw a wave of social engagement emerge in revivalist circles, dealing with the social problems of industrialization and urbanization: Missionaries targeting prostitutes and their customers, institutions for rehabilitating prostitutes and at-risk girls, the establishment of Sunday schools, societies for the erection of churches, organized poor relief, societies for the promotion of keeping the Sabbath holy, youth associations, and temperance and abstinence associations. The initiatives taken in this period were profoundly new in a Danish context, where social work had for a long time primarily been a concern for the state, municipalities, or the nobility, leaving the local priest as essentially a civil servant in the state-church (T. Knudsen 2000; Markkola 2010). The historical importance of these initiatives is shown through the fact that the emerging organizations eventually became a central part of the Danish voluntary sector (Henriksen and Bundesen 2004).

This activity is an early case of civic action, where "participants are coordinating action to improve some aspect of common life in society, as they imagine society" (Lichterman and Eliasoph 2014, 809). More specifically, to distinguish it from the activity of social movements, it will be considered a case of voluntary social action or 'non-contentious collective action' (as opposed to what Tilly describes in e.g. Tilly 2012), where the main focus of the activity is not the making of claims that bear on someone else's interest to a central authority, but the undertaking of social work 'in the shadow' of this authority. ${ }^{1}$

The fact that this activity first emerged in Lutheran-Pietist revivalist circles raises a host of questions: What role did revivalist ideas play in the emergence of voluntary social action in Copenhagen? What role do ideas play in the emergence of civic action in general? How was it possible for such voluntary activities to emerge from a Lutheran tradition that had traditionally seen 'good works' as primarily an obligation of the state and thought the Christian to be justified through faith alone?

\footnotetext{
${ }^{1}$ The roots of such activity can of course be traced to a variety of religious sources, in the Protestant areas primarily the benevolent and friendly societies of antebellum United States (Griffin 1983; Smith 1976; Haskell 1985a; Haskell 1985b), and of the UK (cf. Beveridge 1948), as well as the diaconal tradition in Germany (Beyreuther 1962), and the puritan denominations of Quakers, Methodists, and Baptists (cf. Thompson 1963). This is, however, not the focus of this paper.
} 
Protestant Ethics-In-Action

Published in European Journal of Sociology

This article seeks to answer these questions and consequently has a threefold aim.

First, the aim is to empirically demonstrate the role of religious ideas, specifically in the Lutheran tradition, in the historical emergence of voluntary social action. The historical case of revivalism and voluntary social work in Copenhagen clearly shows how religious ideas both retarded and stimulated this activity, and how it took several innovations in the religious 'schemas' to find a formula that both supported the new activities and resonated with the Lutheran-Pietist revivalist tradition. It is thus shown how ideas mediate between the experience of suffering and the action undertaken to alleviate the suffering, so that ideas of worthiness, the span and character of one's obligation, the justification of civic action, as well as the appropriate means will shape the action undertaken.

The article's second aim is consequently to contribute theoretically and empirically to what seems to be an emergent field of the role of ideas at the level of collective action. Recent research in contemporary civic action has opposed the decontextualized quantitative Neo-Tocquevillian approaches and emphasized the role of action (e.g. Lichterman and Eliasoph 2014), and others have theorized culture and agency in associations on a theoretical level (so called "civil society 4") (Perez-Diaz 2014). There is still much to be done, however. 'Culture-in-action' approaches have been elaborated theoretically (esp. Swidler 1986; Sewell 1992; Mann 2012), but the role of ideas or culture in collective action has only recently been taken up in historical sociology of collective action in the analysis of the emergence of the first social movements in the USA (Young 2006).

The third aim is to renew the attention to European civic traditions. While there has been a great deal of historical-sociological research in civic traditions from the USA, most prominently of course by scholars such as Theda Skocpol and Robert Putnam (Skocpol and Fiorina 1999; Skocpol 2004; Putnam 1994; Putnam 1995; Putnam 2000), research on European traditions is more sparse, and are often concerned with 'deep' hermeneutical studies in the tradition of Robert Bellah (Bellah 1985), (cf. Joas and Adloff 2007), social movements, or relations between state and civil society (cf. Trägårdh 2007), and less with studying the dynamics of non-contentious collective action in 
Protestant Ethics-In-Action

Published in European Journal of Sociology

itself. Whereas the American research often takes place in a state vs. society discussion (Skocpol 1997), this problem is less urgent in Europe, where the state is more accepted as provider of social services. Here, the problem may be to even acknowledge the civic traditions that do exist. ${ }^{2}$

By going back to 'creative juncture' (Joas 2013), where new forms of acting and thinking were innovated from cultural traditions, in an unsettled period where ideas took on the explicit character of ideology one might see more clearly how strong civic traditions emerge, and show the role of ideas in this process as 'midwifes' helping the experience of suffering of others give birth to action; ideas that eventually became 'habits of the heart' in civil society (Bellah 1985).

These considerations lead to the following research question, guiding the analysis:

How did central cultural schemas of Protestant revivalism contribute to the emergence and form of voluntary social action in late $19^{\text {th }} /$ early $20^{\text {th }}$ century Copenhagen?

The article will first introduce the theoretical framework and methodology before moving on to the analysis of the three waves of revivalism that informed the voluntary social action in Copenhagen at the time.

Analytical inspirations: Cultural schemas and the first US national social movement Michael Young's study of the emergence of the temperance and antislavery movements in antebellum United States provides an excellent starting point for thinking about culture and collective action (Young 2002; Young 2006).

Young correctly points out the missing focus on the role of cultural ideas in the contentious politics approach of Charles Tilly and Sidney Tarrow as well as the life politics approach of Giddens, Calhoun and others (Young 2002, 665). I order to remedy this, Young draws on a large host of what you might call pragmatist cultural sociologists (because of their emphasis on action): Mann

\footnotetext{
${ }^{2}$ Kahl reports that civil servants in Denmark, when interviewed, were hardly aware of the existence of a third sector (Kahl 2005, 115, note).
} 
Protestant Ethics-In-Action

Published in European Journal of Sociology

(Mann 2012), Swidler (Swidler 1986), Sewell (Sewell 1992), as well as American pragmatism (Dewey 1991). ${ }^{3}$ He consequently argues that the first national social movements in the USA emerged as the result of a creative "collective adjustment" of cultural schemas in which the affectively intensive schema of public confession merged with the extensive schema of national sin and was appropriated or 'transposed' to the new context of social movements (Young 2006, 34; 203f). The evangelicals re-interpreted the political, economic, and religious unrest of their time as feelings of guilt that had to be redeemed - feelings that then became the 'sounding board' for the adjustment of cultural schemas (37).

In the following I will show how the Lutheran-Pietist cultural schema of sin allowed for a way of engaging with the 'social question' that other moral projects were not able to, and how innovations in various aspects of the religious schemas allowed missionary work to develop into social work. Further, it will be shown how not all innovations resonated equally well with the existing revivalist schemas. It thus took several re-interpretations until the schemas were found that were able to combine the doctrine of justification by faith alone with that of good works. As opposed to Young's interpretation of the early social movement as a 'sounding board' for general societal developments, this interpretation sees the voluntary social undertakings as an adequate rational response, according to the norms of the group, to changes in lifestyle in society. It thus emphasizes this as a deliberate and political response rather than a function of general developments. I would propose with Joas to interpret the creative innovations analyzed below as the emergence of strong value commitments (Joas 2000). The innovations in cultural schemas are in this case provoked by the experience of suffering of others, giving rise to feelings that are then articulated in the available moral vocabulary in an interpretative circle that may in turn alter the feelings as well as the vocabulary (Ibid., 113f; 133f). This process takes place in a 'quasi-dialogical' relationship between actor and situation (Joas and Beckert 2006, 274), where existing values are not simply 'applied', but creatively re-interpreted. There is thus no primacy to experience, ideas, values, or action, since they occur together.

\footnotetext{
${ }^{3}$ Other interesting scholars working within this tradition are Amy J. Binder and Julian Go (Binder 2002; Go 2008).
} 
Protestant Ethics-In-Action

Published in European Journal of Sociology

It is necessary, however, to nuance the culture-in-action approach in order to describe in more detail the role of ideas in this type of collective action. In order to act collectively, the individuals involved need to know why they should act, what the span of their obligation is, and what the appropriate means of action are. Young's 'merging schemas' explanation does not consider theoretically the innovations in doctrine that he also describes, namely the conservative Calvinist doctrine of pre-destination and the Arminian doctrine of free will, that legitimated these religious innovations (Young 2006, 62-65). This on the one hand means that he does not link his work to the extensive literature on the influence of Protestantisms in different fields, and on the other it begs the question if the concept of schemas can cover all of the various functions of religious and cultural ideas. What is proposed is the analytical tools for a 'collective soteriology': Ideas necessarily involved in projects aiming at collective salvation, in this world or beyond.

First, attention is paid to the role of religious doctrines. As more recent developments in the Weber-literature tell us, doctrines are 'contextually selective', that is: Foundational texts are constructed and interpreted in specific contexts with specific purposes, and addressing specific audiences (Zaret 1995). This means that doctrines should not be seen as closed systems, but rather as being 'called to life' in action in order to achieve something. This does not mean that they do not have effects beyond the moment they are enacted. Gorski has for instance shown how Pietists adhering to the 'sola fide' doctrine were instrumental in bringing about the modern Prussian state during the $17^{\text {th }}$ and $18^{\text {th }}$ century (Gorski 1993, 304ff). Likewise, Kahl has shown how Catholic, Lutheran, and Calvinist doctrines have been decisive in the way that nation states have dealt with poverty, e.g. in their proclivity towards outdoor relief or work houses (Kahl 2005; cf. also Manow 2008; Kersbergen and Manow 2009). So, religious doctrines do have long term effects, but only as resources of interpretation that depend upon actors to enact and re-interpret them in new contexts for new purposes. ${ }^{4}$ Seen in this way, doctrines provide the basic articles of faith (whether religious or not) in terms of a more or less coherent system of ideas around which to rally in specific action situations and are thus central in creating the world view of a group (cf. Swidler 1986, 279). Since doctrines are fundamental, the doctrine invoked in a specific situation

\footnotetext{
${ }^{4}$ Interestingly, to my knowledge such a 'Protestant ethic of'-analysis has not been done in the field of social voluntarism. Eriksen (Eriksen 1988), however, has laid the groundwork in the case of the Danish temperance movement.
} 
Protestant Ethics-In-Action

Published in European Journal of Sociology

has implications for the ideational practices that are undertaken. In a Protestant context, for instance, it matters if you refer to the doctrine of justification or sanctification, because certain ideas of community, reciprocity, and conversion are implied (cf. McGrath 2005).

Second, the analysis focuses on ideals of community. Christianity, according to Jaspers and his followers, is an axial age religion and as such a transcendental religion implying the idea of a universal brotherhood of man (Joas 2014). Reiterating the notion of the situatedness of ideas, any commitment to such an idea of universalism must be specified in the context of concrete action (Joas 1999; Joas 2013). ${ }^{5}$ The ideal of community specifies responsibilities and rules for entering and exiting the community to be established (cf. Janoski 1998). The rules of entrance may include certain tests that an applicant may have to pass in order to be accepted in the community, just as there are certain rules that cannot be violated without being expelled from the community. These processes can be swift or prolonged. Once in the community, you are expected to adhere to the formal or informal obligations. This includes the expectations for leaders and followers, and for behavior towards individuals within and outside the community, e.g.: Are outsiders possible converts that can only be saved by joining the revivalist community or can the obligations of the congregation also include the alleviation of suffering without immediate conversion?

Third, the concept of recipe beliefs is introduced. Recipe beliefs constitute techniques for how to remedy the social problems that are identified. The term is inspired by (Haskell 1985b), who seeks to show that the modern 'humanitarian sensibility' as expressed in the $19^{\text {th }}$ century antislavery movement is in large parts the result of the effects of market discipline, or the spread of the norm of 'promise keeping' in contractual relations, as Haskell puts it, and the concomitant spread of technological 'recipe knowledge', effecting both an increased internal moral scrupulousness and an external widening of the span of one's obligations because of the factual ability to affect distant strangers due to technological (in the widest sense) innovations (Ibid). 'Recipe knowledge' has affinities to Tilly's 'repertoires of collective action' (cf. Tilly 1993), but the term also implies a sense of causal connection to a specific problem. Haskell's point is that it is not enough to simply adhere to a certain moral principle or convention; you also need to be able to act on your principles in

\footnotetext{
${ }^{5}$ If one is not to give everything away as in the case of Weber's mystic (Weber 1988, 546)
} 
Protestant Ethics-In-Action

Published in European Journal of Sociology

order for them to have any effect. When you (believe to) have a recipe for dealing with some sort of problem, the problem moves from a category of indifference, of moral neutrality, to the category of responsibility. ${ }^{6}$ I prefer, however, to use the term 'recipe beliefs', since what actually matters, is the (tested or untested) belief that your action have an effect - most evident, of course, in the sphere of religion, where one cannot obtain direct proof of how to obtain salvation. The important take away here is that ideas not only influence action, but that possibilities of action also inform and alter ideas, as in this case when various techniques for social work have been historically developed, such as the 'home', the self-help group, or the pledge of sobriety.

Before putting these concepts to work, a caveat is in order: Ideas serve many purposes, and one major divide in the social study of ideas is between ideas as weapons and ideas as resources for action. This article does not focus on ideas as weapons; as external justification in a social context (cf. Skinner 2002, 177). Even if the case definitely warrants such an analysis, since the social volunteers in Copenhagen were engaged in a battle with socialists and so called 'cultural radicals' that based their projects on very different (and atheist) visions of society, the focus here is on ideas' ability to inform actors' experience and action, regardless of the actors' possible bellicose intentions. The article also does not analyze this as a case of 'social control' where a privileged class launches philanthropic endeavors in order to uphold their position (cf. Banner 1973). Many of these pioneers in social work supported the socialists' claims for labor rights, even if they may have shaped their concrete activity, their 'imagined society' in their own image (Lützen 2002), so the relation between class interest and voluntary action is at least more complex than assumed by some (cf. Haskell 1985a).

The analysis will show how 'soteriological' innovations in doctrine, ideals of community, and recipe beliefs led to the emergence of three distinct approaches to voluntary social work in the Copenhagen case, how revivalist ideas were both enabling and constraining in this regard, and why they were successful or not in terms of 'resonating' with existing schemas, as well as the particular form the voluntary work took on, especially in terms of their 'publicness' and emotional intensity.

\footnotetext{
${ }^{6}$ Haskell uses the image of the invention of a technology whereby you were suddenly able to save a starving stranger just by pushing a button. Would it then not be immoral not to do it? (Haskell 1985a:356).
} 
Protestant Ethics-In-Action

Published in European Journal of Sociology

\section{Method and analytical strategy}

The analysis is a single case study, but will include references to similar European developments in order to illustrate the transnational character of the developments. The single case study allows for an analysis that is close to the actors involved. In order to understand the experiences that triggered the innovations in schemas, I will start by outlining the situation in the rapidly growing city of Copenhagen, particularly in the cases of alcohol consumption and prostitution that became two focal points of the revivalist voluntary initiatives. Then some background on the special Danish organization of revivalism as 'sects within the church' is offered, before analyzing three innovations of revivalist schemas.

The first part of the analysis relies primarily on secondary sources of the rather well researched organization of the Home Mission, while exemplifying the moral language of the group through a central text by its leader, Beck. The analysis of the second generation of urban revivalists builds on programmatic and autobiographical writings of some of the leading social revivalists in primarily Denmark, but also Germany and the Netherlands, as well as the work of historians. The third analysis relies primarily on secondary sources on the Holiness Movement in Denmark and the US.

\section{The situation}

The social question, relief systems, and life politics projects in 19th century Denmark Copenhagen grew explosively from 120.000 inhabitants in 1840 to 234.000 in 1880 (Malmgart $2002,8)$. As in other large cities in Europe before, the so called 'social question' emerged. Or rather, social questions emerged, since the question had several aspects and was perceived in various ways, depending on group affiliation. The social question was thus also related to questions of 'life politics', questions of morality and lifestyle.

The city presented the rural immigrants with a 'float or sink'-situation, where the risk of pure material deprivation was intertwined with problems related to new patterns of interaction between strangers and new opportunities of consumption. Here, two main risks came to fall within the purview of the home missionaries: alcoholism and prostitution. 
Protestant Ethics-In-Action

Published in European Journal of Sociology

The industrialization of beer production led to stronger types of beer, and the consumption of distilled spirits increased. Alcohol seems to have been a way to cope with trauma and social problems, for instance by soldiers involved in the bloody Danish - Prussian war of 1864 (Eriksen 1991). Furthermore, the new sociality that arose with urbanization meant a relaxing of social control and traditional ways of alcohol consumption, while at the same time making consumption of alcohol more visible and thus easier to construe as a problem (Gundelach 1988, 163). Prostitution had at this time been legalized as a measure to combat the growth of venereal diseases. This meant forcing women who had been caught a third time trading sexual favors for money to register as a 'lady of the night' and to be confined to certain areas of the city (Bøge Pedersen 2007).

The state's social relief systems were not geared towards the new risks of urban and industrialized society. While Pietism and Enlightenment ideas had guided the construction of a generous welfare system without means testing in the late $18^{\text {th }}$ century (Sørensen 1998), the rise of the bourgeoisie to power in 1848/9 led to an increased focus on being able to distinguish between the deserving and the undeserving poor. This was primarily done through the deprivation of civil and political rights entailing the loss of the right to marriage, the loss of property rights (Ibid., 370), and the deterrence and disciplining of poorhouses. These were however, quite crude tools for dealing with the question of the potentially underserving, the youth that might give in to the temptations of the city, as well as the moral reformation of those that had already succumbed to alcohol or promiscuity (cf. Lützen 1998; Malmgart 2010; Kofoed 2014).

The situation in Copenhagen thus represented a very real call for action due to the emerging social and life politics questions. The political elites thought of poverty in moral terms. One should not encourage the poor to seek relief, but discourage or discipline them through the poor house. However, with this renewed emphasis on moral categories as the access point to social welfare, a new host of problems emerged: Drunkenness, gambling, promiscuity, lavishness, indolence etc. Here, the Home Mission presented itself as an actor that had a vocabulary for dealing with moral issues in contrast to the material focus of the socialists, the aesthetic evaluation of the 
Protestant Ethics-In-Action

Published in European Journal of Sociology

bourgeoisie, or the parts of the mainstream currents of the church that focused primarily on alleviation of poverty.

The three waves of voluntary social action in the Home Mission

The Copenhagen Home Mission grew to become the nub of the voluntary social work that was undertaken in the capital towards the end of the century. We now turn to the analysis of the innovations in religious schemas that enabled, hindered, and enabled once again the integration of voluntary social action into the Lutheran framework of justification by faith alone.

Revivalist pietism: Faith alone

Established in 1861, "Indre Mission" (Home or Inner Mission; HM from now on) grew out of the early 19th century revivals. ${ }^{7}$ It had its basis in local societies in the rural areas, but was centrally controlled by priests belonging to the national church, though with a high degree of local independence (Lindhardt 1978, 84-92; Gundelach 1988, 112-15). The association was from the onset largely controlled by the controversial and highly influential priest Vilhelm Beck, who officially became leader of the association in 1881 and remained so until his death in 1901.

The HM established itself as one of the four major branches of the national church, and the most conservative branch at that, emphasizing a literal reading of the Bible, the impossibility of conversion after death (thus stressing the importance of proper behavior in this life), and the abstinence from adiaphora such as dancing, drinking, and card games (Lindhardt 1978, 70f).

In terms of doctrine, the HM emphasized the Lutheran doctrine of "sola fide", justification by faith alone. In this regard, the organization was truly an offspring of the early revivals that marked a creative juncture within the Protestant churches. The earliest revivals in Denmark, as in other European Protestant areas (Beyreuther 1977), were protesting their priests' and the state church's rationalist teachings. Rather than the practical Enlightenment teachings that put man at the center of religion, and saw God in an assisting role, the revivalists emphasized that salvation was

\footnotetext{
${ }^{7}$ The early introduction of freedom of religion and the establishment of a broad national church in Denmark had the effect of maintaining the religious revivals inside the national church - as opposed to another Lutheran country, Sweden, where freedom of religion came late, and the sects, consequently, grew outside the national church (Eriksen 1988).
} 
Protestant Ethics-In-Action

Published in European Journal of Sociology

achievable only through inner faith. In line with Luther, who had launched the doctrine of 'sola fide' as an answer to the Catholic practice of selling indulgences, man along with the world as such, came to be seen as wholly depraved and unable to change this state through action. This meant that being in a state of grace could only be assumed through an inner conviction, and not be interpreted from outer signs such as fortune in business dealings or secured through good deeds. Since this world was seen as sinful and primarily as a preparation for the next, the alleviation of suffering in this world came to mean less than saving souls for eternity.

Luther had himself emphasized in his teachings that even though salvation was solely a matter of faith, good deeds played a part in as much as faith must 'bear fruit' (Gorski 1993, 292). Beck and the HM with him followed this thinking. The Mission did thus not have strong concepts for the role of charity in their theology. It was actually rather treated as a 'middle thing', neither encouraged nor discouraged, a thing that the local communities could take up if they wanted. It was simply not a concern for the HM, and when Beck did deal with charity, he emphasized its possible good effects for faith (Larsen 2000, 236). Following this logic, the HM also opposed the temperance movement when this emerged in a mainly secular version in Denmark at the end of the century. Rather than seeking out a pseudo-religion, people should seek Christ and join the Mission to combat their vices (Eriksen 1988). The doctrine of sola fide thus led the Home Mission's to adopt a reluctant attitude towards organized charity, and in this way failed to develop a language for social work, as for instance the institution of the diaconate could have constituted. ${ }^{8}$

What the HM did have a language for was sin and morality, and this influenced the organization's ideal of community. As in Puritan Calvinism, the wholly transcendent God, and the inability of the individual to secure her/his own salvation meant a search for being on the right side of the saved/lost divide. The Pietist moral teachings thus became a means of distinguishing the 'children of God' from the 'children of the world'. Even if the leadership did not condemn drinking, playing cards, or dancing as sin, there is evidence that these activities were perceived by many of the followers of the movement as clear markers as to whether one belonged to the saved or the lost (Holt 1979, 471ff). On this backdrop, the Home Mission communities evolved, as did other

\footnotetext{
${ }^{8}$ Beck actually supported the revival of this institution in principle, but failed to develop it in practice (Larsen 2000:110f).
} 
Protestant Ethics-In-Action

Published in European Journal of Sociology

revivalist groups, into 'subcultures' with their own specific way of dressing, their own formula for greeting and talking, and their own practices of endogamy, i.e. finding spouses within their own group (Balle-Petersen 1977; Balle-Petersen 1986). The ideal community was thus one of pious Christians that were not slumbering, but were truly awakened in their faith; a faith that could be recognized through a certain moral behavior and a certain 'code' language.

The sharp divide between saved and lost also meant that the obligations to individuals inside and outside the community were immensely different, and the recipe beliefs or religious techniques applied varied accordingly.

Internally, the 'Ordo salutis', or the steps to salvation, took on a distinctive form. Rather than the progression towards moral perfection that was the mark of certain strands of Calvinism, the techniques of the Home Mission had no progressive element. Rather, there was the constant threat of falling out of grace. Beck in a central sermon uses a rural metaphor in that he compares the corn cockle (a type of beautiful weed) in the wheat field to the sins in man. The corn cockles have been planted by the devil, and since we do not know one from the other before the Last Day, the true Christian should every day watch for the corn cockles within himself (Beck 1872). Internally in the community, we can thus we can talk of a religious technique of vigilance, ${ }^{9}$ of persistent self-surveillance, watching over one's behavior and thoughts.

Externally, the Home Mission stressed the individual conversion or rather the 'awakening' of the dormant Christian. This type of awakening traces back to influences on the early awakenings from Pietism and the Moravians (Olesen 1983). With the institutionalization of the revivals in the Home Mission, the experience of awakening was toned down in the official theology, so that 'rebirth' happened through the church's sacrament of baptism, where the totally depraved human being received the gift of grace, and became justified in the eyes of God. Conversion ought not to take place, once you were baptized, but if you were to lose sight of your covenant with God instigated through baptism, a 'deep' conversion would be necessary, 'back to' a life of renunciation and belief (Larsen 2000:32-48). Rather than the minutely detailed description of the violent

\footnotetext{
9 'Spiritual vigilance' was the theme of at least one devotional re-publication by the Home Mission (Larsen 2010:96)
} 
Protestant Ethics-In-Action

Published in European Journal of Sociology

'Busskampf' of the Pietists, the conversion techniques used by the home missionaries consisted of addressing possible converts in a direct manner: "Have you met Jesus?", the singing of psalms, and handing out of tracts and distributing of Bibles (Larsen 2011, 59ff).

In the local communities, however, sin and moral conduct in a sense remained 'private', and the techniques were 'silent'. To rid oneself of sin, one needed to return to the covenant of baptism, which in practice meant to join one of the Home Mission's communities, and work with the outside world had the final aim of conversion. The techniques were 'silent' in the sense that it was practiced by singing emotional psalms, especially Pietist versions, and reading devotional literature aloud, while preferring coffee to alcohol, and singing to dancing - and by sticking to your own kind through endogamy (H. Knudsen 1984, 10ff; Balle-Petersen 1977; Balle-Petersen 1986).

When the HM launched its Copenhagen branch in 1865 (CHM from now on) with an independent, self-supplying board, the means undertaken in regards to alleviation of poverty reflected these kinds of techniques. The mission's stance to charity was not opposed to private charity, but the main aim of the HM was always primarily religious, and charity or voluntary initiative was secondary - a means to do mission or in the Lutheran vocabulary: a fruit of the true beliefs. It was something that the local congregations could carry out, but not a task for the organization as such (Larsen 2000, 110-13; Larsen 2010, 36-40). The situation in the city, however, prompted the Mission to take use more public forms of missionary work. The social problems in the city were interpreted in the language of sin; Copenhagen as Satan's Capital in Denmark (Lützen 1998, 288), where loose morality was the order of the day. Consequently, a kind of mission was required that did not solely focus on saving souls, but also on raising the morals of the citizens, if salvation for all was to be achieved. Such work had been started by private individuals and subsequently incorporated in and supported by the Mission in the capital. Besides spreading the message of the gospel in the destitute areas of the city, these missions targeted the centers of sin: The pub and the prostitution districts (so called 'Midnight missions'), where prostitutes and pub owners as well as their 'customers' were confronted, Bible in hand, with their sinful ways (e.g. Thomsen 1904). 
Protestant Ethics-In-Action

Published in European Journal of Sociology

The HM's entry into the capital did not change the cultural schemas of doctrine, ideals of community or recipe beliefs significantly. They were 'transposed' in a rather direct manner, as the new questions of the city were combatted within the well-proven missionary vocabulary: Faith was imperative as the only way to be just in the eyes of God, and as such charity, philanthropy etc. could only be understood as 'fruits of faith', as almost accidental byproducts. The encounter with urban life did initially not change the goals of the organization, only the missionary means, the recipe beliefs, changed from focusing solely on salvation to becoming 'moral missions', targeting the public sins of alcohol and prostitution.

The language of sin, however, provided an articulation of the social question that was more readily transformed into social work than the projects of the socialists or the J. S. Mill-inspired cultural-liberals where the road to salvation went through the rights of the state or the demolishing of existing gender norms, respectively.

\section{Social Pietism: Faith active in love}

CHM's initial Lutheran-Pietist approach to 'social work' did not attract many followers, and the board was reconstructed in 1875, as a new generation of younger priests and laymen took control, most prominently the priest Harald Stein, elected chairman in 1879 , who came to articulate most clearly the ideology of the organization (Holt 1979, 36f).

This new generation constituted a 'moral elite' of priests, civil servants of various professions, and merchants, less occupied with the 'divide' between saved and lost, and more with Christianity as a moral force. The mission in the capital soon became a field of struggle between ideas and methods of the HM, and new impulses from abroad, summarized in the time as a 'mission of words' vs. a 'mission of deeds'. The new generation was part of a wider international network of 'second generation revivalists', encompassing the German Lutheran "Erweckungsbewegung" and the Reformed continental movement "Le Reveil". The most influential initiatives in this movement were taken by the Lutheran priest Johann Hinrich Wichern, who had founded the educational institution for boys 'Das Rauhe Haus' near Hamburg, Germany, in 1833, and the reformed Protestant pastor Otto Gerhard Heldring who founded the asylum for prostitutes 'Steenbeek' in 
Protestant Ethics-In-Action

Published in European Journal of Sociology

Guelders in the Netherlands in 1849, but also Stöcker, Bodelschwingh, and the London City Mission were part of the network (Schram 1978; J. Stein 1933, 40;44; Olesen 1964, 27f; Steen and Hoffmeyer 1915, 55).

Stein's programmatic series of lectures from 1876 can safely be taken as the ideological manifesto of this current that inspired the explosion in voluntary social work in Copenhagen. It was reprinted several times and also translated into German. Stein here laid out three 'missions' based on the 'deeds of love': preserving (protecting children and the youth), saving (outreach to the fallen: prostitutes, prisoners and drunkards), and comforting love (helping the poor, the sick and the helpless). The lectures are a peculiar mix of indignation regarding the social conditions especially in the city, where Satan has free reins, combined with regret over the state of a Christian community that does not act on this, as well as practical directions for doing social work gathered from the European network.

Stein's lectures mark an innovation in Protestant thought in Denmark, ${ }^{10}$ where for the first time an appeal was made for the congregation to take voluntary social action, and not rely on the priest or the state, who was thought capable of delivering the last "kiss of Judas" to the church (H. Stein $1872,127)$.

Merging the doctrinal schema of 'sola fide' with what could easily be construed as the detested schema of 'works' required some theological consideration. How could the organized obligations of the Christian be formulated without falling back on a Catholic kind of justification through deeds? Here, the 'magic formula', so to speak, became the merging of faith and love through Luther's formulation of faith active in love (Forell 1999, 70-111). Though salvation was still only obtainable through faith, this faith was expressed in the idea of neighborly love, which showed itself through deeds. The Christian is thus moved to act on his love, and in a sense it is not the Christian as such that acts, but love that acts through the Christian: A love that 'saves', 'protects', 'helps' etc. These formulations served to combine the purely inner relation to God on the one hand with an emphasis on action on the other that avoided both what was seen as the Catholic

\footnotetext{
${ }^{10}$ Even if he was inspired heavily by the priest of an earlier generation, Martensen's, thoughts on Christianity and socialism (Martensen 1874).
} 
Protestant Ethics-In-Action

Published in European Journal of Sociology

mistake of perceiving good deeds as a way of securing salvation and the almost equally mistaken rationalist theology that emphasized Christian 'virtues' in everyday life (Dubois 2010; Lieburg 2012; Van Drenth 2002; Beyreuther 1962, 25ff; 88-96; Wichern 1956a, Bd. 1:151f and passim; esp. Shanahan 1954, 70-94; H. Stein 1882, 11 and passim).

Staying within the HM revivalist tradition, the 'social question' was still perceived in moral terms, so that attention was paid to the "Sittlichkeit"-side of the question, even if some of the leaders of the movement touched upon structural aspects as well (Wichern 1956b, e.g. 258f): Prostitution, indecency, the breakdown of the family, alcoholism etc. These questions were taken up in the language of 'sin'. The city, especially, was perceived as a place where sin flourished in the form of dancing establishments, bars, and unsupervised youth. The city was portrayed in this way in Denmark, Germany, Holland, and the UK (H. Stein 1882, 85, 93 and passim; Wichern 1956b; Van Drenth 2002; Guthrie 2015).

Even if the social question was still perceived through the cultural schemas of the revivalist tradition, as sin, the ideals of community and the recipe beliefs changed, and thus also the ordo salutis from the shackles of Satan to salvation.

The social Pietists' main innovation can be said to be a change in the nature of the obligations of the congregation. Women, drunkards, criminals, etc. were seen as weak, as 'fallen', that is: as essentially passive victims of a sinful society; the congregation, the ones who had already found faith, hence carried the responsibility to act. Stein held up the congregations of the early churches as an example of the active congregation (H. Stein 1882, 1-19), while Wichern in Hamburg, like Spener before him, invoked Luther's concept of universal priesthood (Wichern 1956a, Bd. 1:37).

The recipe beliefs or techniques for treatment were developed chiefly by combining the older idea of the institution or the 'Anstalt', not least inspired from the German diaconal tradition, with 'modern' pedagogical means based on 'family principles' and the idea of voluntary participation. So for instance, the 'Magdalen homes' ${ }^{\prime 1}$ for the rehabilitation of prostitutes in Holland and

\footnotetext{
${ }^{11}$ Ostensibly, the first 'Magdalen Home' was founded by Quakers in Philadelphia, USA, in 1800 (cf. Cunzo 1995).
} 
Protestant Ethics-In-Action

Published in European Journal of Sociology

Denmark were explicitly based on the idea that the 'fallen' women were free to leave at any time, symbolized in Denmark by the ritual of showing that the door to the facility could be unlocked by anyone on the inside, just as the institutions were called 'homes' to resemble family life, and the superintendent considered him or herself a 'father' or a 'mother' of the family (cf. Esche 1920). Here, Wichern's ideas from his 'Rauhe Haus' institution (est. 1833) for 'street kids' had been groundbreaking. Wichern had developed a 'theological pedagogy' built on forgiveness, trust, education to freedom, an individual approach, where a book was kept for each child, and the 'family principle', where older 'brothers' took care of younger ones (Beyreuther 1962, 93; Anhorn 2007). These ideas proved powerful and effective to a rising bourgeois middle class that sought to act on the experiences of poverty and deprivation in the city, and in Copenhagen a range of initiatives were taken, including homes for children, nurseries Sunday schools, Bible classes for the youth, and 'young men's associations', missions for maids and 'factory girls', soldier and seamen's missions, as well as institutions for epileptics (Olesen 1964, 28-31).

While the schemas of love and recipes of voluntary work resonated well with the wider national church and the bourgeoisie that came to differentiate sharply between the rural HM and CHM (cf. Steen and Hoffmeyer 1915, 115ff), the social Pietist merging of the doctrinal schemas of faith and love did not resonate with the revivalist schemas of the laymen in the CHM and the rural HM and this was the case in Germany and the Netherlands as well. In Copenhagen, the rural Home Mission criticized the approach for being a 'mission of deeds' rather than a 'mission of words', besides casting suspicion on the initiatives as a kind of 'German' mission, which was not popular after the Second Schleswig War of 1864 between Prussia and Denmark (Holt 1940, 51), and Stein eventually retired as chairman of the CHM board. In Germany, similar criticism from the orthodox Lutherans were raised against Wichern, who was accused of "by the jingle of good works to seduce the Protestant church to idolatry" (Janssen 1956, 35 my translation), just as Wichern's vision of the universal priesthood did not resonate with the 'Erwerkungs-bewegung' (Janssen and Sieverts 1962, 143). And in Holland, the translation of German Lutheran thoughts to a reformed Protestant context also proved too difficult for Heldring (Benrath, Sallmann, and Gäbler 2000, 72f; Lieburg 2012, 120;134). 
Protestant Ethics-In-Action

Published in European Journal of Sociology

At this point, however, a 'louder' and more public theology than the inwards looking 'quiet' and private Pietism was to enter the continent: That of the Holiness Movement. ${ }^{12}$

\section{Holiness Movement: Sanctification and public recipes}

What can be called the 'third generation' in and around the Copenhagen Home Mission was heavily influenced by holiness theology and practice. Stein's stepping down as leader of the Copenhagen Home Mission in 1886 has been interpreted as a victory for the rural home mission (Holt 1979, 39), but even if the capital branch now declared its allegiance to the national (rural) Home Mission, it is probably more accurate to say that it was a certain type of Protestantism that triumphed.

If we take a look at the layer beneath the leadership of $\mathrm{CHM}$, the practitioners or laymen, then we see that many of these were inspired by holiness-ideas. During the battle between the rural and the urban Home Mission, Beck in 1898 asked publicly for the support of the laymen in CHM. He got the support he wanted, but more importantly for our purposes, the response from the laymen (published in the Home Mission periodical) ended with the greeting that they had a common purpose in "human souls' conversion and sanctification" (Holt 1979, 59ff).The mention of 'sanctification' shows that the holiness teachings were now part of the vocabulary among laymen, and we see how several of the 'workers' in the Home Mission were influenced by this line of thinking, so for instance Thora Esche (cf. Esche 1920), leader of the Magdalen Home for prostitutes, Colonel Christian von Keyper and his wife Therese, who were active in the Sunday school work, as well as city missionaries such as R. B. Clausen, initiators of the temperance organization 'The Blue Cross', the librarian H. O. Lange and the priest H. P. Mollerup. The latter also co-founded the Holiness-inspired Church Army in Denmark. Finally, the leader of the YMCA in Denmark was also influenced by these teachings. These are but a few examples, but there are many more, and they are well documented (c.f. Olesen 1996, 571-89).

\footnotetext{
12 There may be an affinity between Reformed Protestantism and the city, and Lutheranism and the countryside (cf. Tawney 1972) that we will not touch upon.
} 
Protestant Ethics-In-Action

Published in European Journal of Sociology

The Holiness ideas first arrived in Denmark through the interdenominational and international movement The Evangelical Alliance who held their 8th World Conference in Copenhagen in 1884 (Olesen 1996, 231), and quickly came to influence large portions of the revivalist circles around the Home Mission, first in the capital and then nationwide. ${ }^{13}$

The central ideational innovation of the Holiness Movement was the revival of the doctrine of sanctification. In Lutheranism, as we have seen, the dominating doctrine was that of justification by faith alone, whereas sanctification, the process of becoming holy in this life, was of minor importance. The doctrine was first developed in a revivalist way by Zinzendorf and his followers in the Moravian community, who against the Pietist conversion struggle defended their version of the doctrine of sanctification, of freedom from sin, and distinguished between the habitus of sinning and the act of sinning. While man cannot be free from the first, he is free from the last kind of sin, when he has experienced conversion. The ideas were developed further in reformed Protestantism by the father of Methodism, John Wesley, who translated them to the idea of 'Christian perfection': "Exactly as we are justified by faith, so are we sanctified by faith" (Olesen $1996,88)$.

In reality, the doctrine of Holiness turned the image of man - and thus of sin - upside-down. Whereas Lutherans and Calvinists had taught the total depravity of man (to a greater or lesser extent), and especially Calvinists had taught the lack of free will, the Holiness message taught that since Jesus had bled on the cross for all humanity, grace was universally available, sin had already been taken away, and man had only to embrace what had already happened - he was free to choose not to sin. There were more or less radical interpretations of this doctrine: while some used the phrase 'Christian perfection' and counted the days since they laid the old human being behind and stopped sinning, others talked more discretely about 'liberation' from sin rather than total freedom. For the adherent to this doctrine, sin ceased to be a problem.

\footnotetext{
${ }^{13}$ Pockets of holiness ideas were already latently present in Denmark due to the spread of Scottish tract-literature earlier in the century (cf. Eriksen 1988), just as the Moravian communities had spread similar teachings, and the temperance movement had applied Methodist-like techniques in a secular framework (ibid.).
} 
Protestant Ethics-In-Action

Published in European Journal of Sociology

The ideal of the Christian community changed with the doctrinal changes: Old confessional divides were expected to wither away, and a new global community of Christians was thought to arise. This ideal was linked to imaginaries of the second coming of Christ, the expectation that God's rule on Earth was imminent, comprised in concepts such as millennialism, eschatology, and Parousia expectations (of Jesus' imminent return) (Ohlemacher 1986, 173). This was not the wholly transcendent God of Weber's Calvinists, but an immanent God whose presence was deeply felt and experienced. The ideal was concretized in interdenominational organizations such as The Evangelical Alliance, or in single-purpose organizations such as the YMCA, and in Copenhagen in the voluntary initiative 'The Church Foundation' concerned with building new churches for the congregations in Copenhagen. Wesleyan and German Holiness ideals of the congregation as an active, self-organizing community around a strict church discipline were at the center of this initiative - only it should be realized within the bounds of the national church (Bach-Nielsen and Schjørring 2012, 501-2).

That sin was no longer a necessity, that it came from 'without' so to speak, that everyone could will to be free of sin, that God's presence was felt - all these things meant that the eradication of sin was no longer the obligation of a loving and merciful congregation towards those who had 'fallen', as in social Pietism. Rather, it was the question of getting the happy message out: That everyone could be free of sin, if only they would, and using the proper religious techniques. Only, sin did naturally not disappear entirely after all, and a new problem arose: The problem of 'backsliding', of returning to old sinful ways (Olesen 1996, 87). As we will see, these ideas were reflected in the recipe beliefs put into practice in the social work of the movement.

The central innovation in terms of recipe beliefs or religious techniques of the movement was the application of the so called 'New Means'. The New Means consisted in mass conversion meetings, week long camp meetings, private and public prayer meetings etc., where the number of conversions was registered and publicly announced. Since grace was freely available, one only had to declare that one was reborn, and the 'ordo salutis' was thus not the quiet, but violent, internal battle of the Pietists, but the loud and public announcement or testament of having shed off the old sinful nature (cf. McLoughlin 1978, 141ff; Smith 1976, 63-79). The New Means also included a 
Protestant Ethics-In-Action

Published in European Journal of Sociology

louder and more intense interaction between the preacher and the congregation/audience, where especially the Palmers constituted a vanguard in promoting a new form of psalms, where the audience in a seemingly spontaneous, but highly rehearsed way loudly expressed their approval of the sermon through affirming outbursts of 'Hallelujah', 'Bless the Lord!', 'Oh, Lord!' etc. (Olesen 1996, 62f). Whereas in early revivalist Pietism, the breaking of the fiddle had been a sign of conversion, musical instruments now became integral for the conversion process - to the point where the guitar became the ultimate sign of Holiness-adherence (Olesen 1996, 256). Moreover, there was a 'magical' element in the Holiness Movement. The more radical believed in the power of faith and the Holy Spirit to cure diseases, and this intuition was also present in the less radical forms, such as faith's ability to heal the social illnesses and individual sinful habits (Ibid.: 221-4; 243-252).

Rather than the "Anstalt" (institution or asylum), the main recipe for dealing with moral-social issues now became what could be called the 'abstinence association'. Temperance and abstinence are concepts mostly associated with the 'moral crusade' against alcohol consumption, but temperance or abstinence became a widespread technique that Christians formed associations around. Abstinence was applied to combat especially alcoholism (The Blue Cross), sexual promiscuity (The White Cross), and the depravation of youth (YMCA). In the furrows left in the soil by the Holiness revivals, such groups mushroomed (Fleisch 1903, 56-65). In Germany, the Gnadauer Konferenz, a yearly week long Holiness Conference, was instrumental in causing such abstinence associations to flourish. These associations carried the 'public spirit' of the movement by clearly showing adherence though a pin or a ribbon, and interestingly contained elements both of self-help and philanthropy. The abstinence associations concerned with alcohol consumption, for instance, were often started by priests and converted laymen, who in solidarity with the drunkard signed an abstinence pledge (philanthropy), while former drunkards entered the movements and became central members (self-help).

The techniques used in the abstinence associations had a clear affinity with the holiness teachings: The pledge was a way of publicly commit oneself not to sin anymore, and the problem of 'sliding back' into sin was of course ever present, but was handled through techniques of probation and 
Protestant Ethics-In-Action

Published in European Journal of Sociology

quarantines (cf. Granum-Jensen 1979). The goal of the 'ordo salutis' was of course still the salvation of the soul, but since the kingdom of God was here and now, the steps were steps to a life in grace in this life as well. Not only ethics, but salvation itself became inner-worldly.

Telling of the difference between the Social Pietism and the Holiness approach is the fact that Stein did not even believe in erecting asylums for drunkards in Denmark, since the shame of entering one would be too great, and the temperance pledge was too easily broken $(\mathrm{H}$. Stein 1882 , 98ff). This illustrates clearly the irreconcilability of the public and loud Holiness teachings and the private and quiet means of the social Pietists.

In Copenhagen, the Blue Cross (est. 1895) and the Church Army (est. 1912) were started by men inspired by Holiness-teachings, and in their early days, these associations most clearly resemble the ideal type of the abstinence association by building on the solidary engagement of the volunteer with the 'voluntee', through the use of musical instruments, the 'after-meeting', and the idea of human perfection. The Danish YMCA (est. 1878), however, was also clearly marked by the Holiness movement in terms of ideas and persons - and of course the Salvation Army (est. 1887 in Denmark), whereas this organization unlike the others were established as a direct 'branch' of the mother organization.

Paradoxically, it was thus the Reformed cultural schema of sanctification stemming from the Holiness Movement that finally made it possible to integrate 'good works' into the Lutheran revivalist sola fide tradition. This was made easier as these notions also more or less consciously had entered into the rural Home Mission's vocabulary (Olesen 1996, 323-41). Eventually, as the turbulent period settled, many of the initiatives borne by the revivalist civic engagement were integrated into or supported financially by the emerging welfare state, while often continuing to be supported financially and ideologically by the Home Mission adherers (Kaspersen and Lindvall 2008; Henriksen and Bundesen 2004). The once highly controversial question of how to conduct voluntary social work in a Lutheran context thus cooled down and became a civic habit in revivalist circles. Had it not been for the creative reinterpretations of Protestant cultural schemas of sin, works, justification, sanctification, community, and recipes for action, in light of the experience of 
Protestant Ethics-In-Action

Published in European Journal of Sociology

suffering, the so called third sector in Denmark would have emerged in a different form and maybe at earlier or later period in time.

\section{Conclusion}

The aim of this study has been explore a specific, but influential strand of especially European civic vocabulary, that of Lutheran revivalism, through the case of the emergence of voluntary social action in Copenhagen app. 1865 - 1915. Specifically, it has been shown how the Lutheran cultural schema of sin worked both enabling and retarding, how schemas were creatively reinterpreted and merged on the basis of new experiences, and how these re-interpretations emerged concomitantly with new forms of voluntary social action. Cultural ideas thus provide part of the explanation of the who, when and how of the emergence of voluntary social work.

It was the cultural schema of sin that first prompted the revivalists of the Home Mission to engage with the life politics aspects of the social question in Copenhagen at the end of the $19^{\text {th }}$ century. This language allowed for the articulation of and voluntary action upon issues of prostitution and alcoholism better than did the language of rights of the emerging social democracy or the language of liberation of the cultural liberals. It was soon clear, however, that the revivalist framework not only enabled voluntary social work, but also retarded it. The question of how to integrate good works and deeds into a Lutheran context that emphasized that the Christian could only be saved through faith, represented a problem for a revivalist movement that stuck to ideals of community that distinguished unequivocally between the saved and the damned, and consequently only allowed for moral missions that urged sinners to return to God. It thus took two reinterpretations of the Lutheran-Pietist tradition to reach a theological language that allowed for voluntary social work to be integrated into the Pietist religious framework. While the Priests of the social Pietist movement rearticulated the role of deeds and works with the Lutheran doctrine of "faith, active in love" and thus expanded the Home Mission's purely soteriological understanding of their task, this framing seemed to resonate better with the bourgeois public than with the laymen and rural basis of the Mission, who found the ideal of the responsible community and the methods of the institution overly distanced and lacking in religious enthusiasm. Only the second reinterpretation, inspired by Holiness ideas mostly found within the Reformed tradition, 
Protestant Ethics-In-Action

Published in European Journal of Sociology

succeeded in merging the sola fide doctrine with that of works through the addition of the doctrine of sanctification and the resultant re-articulation of the Christian community as consisting of sinners freed from sin, following enthusiastic, involving, and public recipes for voluntary social action, realized exemplarily in the various temperance organizations.

Through this short period of time, a development in soteriology is evident. The path to salvation, the ordo salutis, is reinterpreted so that both the nature of $\sin$ and the means to combat it is altered. For the first generation Pietists, sin is individual and combatted internally through vigilance, while externally only individual conversion to the 'children of God' would mean salvation. For the second generation, sin became a state of being caused by the depraving environment of the city. It was thus necessary to take the first step of removing social suffering, before conversion or 'awakening' was even a possibility. For the third generation, however, the ordo salutis was short: Since sin had already been overcome two millennia ago, freedom from sin and faith, action and word, were inherently linked and immediately realizable.

Theoretically, the aim has been to contribute to the literature on civic and voluntary engagement by analyzing the role of ideas in a case of emerging voluntary collective action during a specific creative juncture in recent history. Religious revivalism represents an especially clear case of value based non-contentious collective action, and so it may be argued the concepts of doctrine, ideals of community, and recipe beliefs could provide an analytical pathway for analyzing other forms of religious or secular soteriologies, of pathways to social salvation, provided that there will always remain a non-rational element in such action.

Recent research (Steensland 2014) has shown how the American evangelical tradition is waking up to engage once again in social questions, but there are vast opportunities to study innovations in religious schemas that restrain or promote specific types of collective action leading to violent action, welfare initiatives, or life politics action. In a European context, it is urgent to understand how various civic vocabularies are rearticulated in order to act on the suffering of refugees escaping the violent conflicts in the Middle East. 
Protestant Ethics-In-Action

Published in European Journal of Sociology

\section{Literature}

Anhorn, Roland, 2007. “'...wir Schmieden Alle Unsere Ketten von Inwendig Und Verschmäen Die, so Man von Aussen Anlegt.' - Johann Hinrich Wicherns Sozialpädagogik Des Rauhen Hauses Und Die Macht Der Individualisierung" in ANHORN Roland, Frank BETTINGER and Johannes STEHR, eds., Foucaults Machtanalytik Und Soziale Arbeit: Eine Kritische Einführung Und Bestandsaufnahme (Wiesbaden, VS Verlag für Sozialwissenschaften).

Bach-Nielsen, Carsten, and Jens Holger Schjørring, 2012. Kirkens Historie. Bind 2 (Copenhagen, Hans Reitzels Forlag).

Balle-Petersen, Margaretha, 1977. Guds Folk i Danmark : Nogle Synspunkter På Studiet Af Religiøse Grupper (Lyngby, Etnologisk Forum, Institut for europæisk folkelivsforskning).

Balle-Petersen, Margaretha, 1986. "Everyday Rainbows: On Social Movements and Cultural Identity." in JONSSON, Bengt R., ed., Arv: Scandinavian Yearbook of Folklore, 42 (Uppsala \& Stockholm, The Royal Gustavus Adolphus Academy, Almqvist \& Wiksell).

Banner, Lois W, 1973. "Religious Benevolence as Social Control: A Critique of an Interpretation", The Journal of American History, 60(1): 23-41.

Beck, Vilhelm. 1872. "Er Du Hvede Eller Er Du Klinte?" in "Nyt Og Gammelt". En Postille, 2nd edition (Copenhagen, Axel Schiødte: 115-23).

Bellah, Robert N., ed., 1985. Habits of the Heart: Individualism and Commitment in American Life (Berkeley, University of California Press).

Benrath, Gustav Adolf, Martin Sallmann, and Ulrich Gäbler, eds., 2000. Der Pietismus Im Neunzehnten Und Zwanzigsten Jahrhundert (Göttingen, Vandenhoeck \& Ruprecht).

Beveridge, William, 1948. Voluntary Action: A Report on Method of Social Advance (London, Routledge).

Beyreuther, Erich, 1962. Geschichte Der Diakonie Und Inneren Mission in Der Neuzeit (Berlin, Wichern-Verlag).

Beyreuther, Erich, 1977. Die Erweckungsbewegung (Göttingen, Vandenhoeck \& Ruprecht).

Binder, Amy J., 2002. Contentious Curricula: Afrocentrism and Creationism in American Public Schools (Princeton, N.J., Princeton University Press).

Bøge Pedersen, Merete, 2007. Prostitutionen og grundloven: regulering af og debat om prostitution i Danmark i perioden ca. 1860 - 1906 (Copenhagen, Museum Tusculanums Forl.)

Cunzo, Lu Ann De, 1995. "Reform, Respite, Ritual: An Archaeology of Institutions; The Magdalen Society of Philadelphia, 1800-1850", Historical Archaeology, 29(3): i-168. 
Protestant Ethics-In-Action

Published in European Journal of Sociology

Dewey, John, 1991. A Common Faith (New Haven, Yale University Press).

Dubois, O. W., 2010. Reddende Liefde: Het Werk van de Heldringstichtingen in Zetten, 1847-2010 (Hilversum, Verloren).

Eriksen, Sidsel, 1988. “Vækkelse Og Afholdsbevægelse”, Scandia: Tidsskrift För Historisk Forskning 54(2): 251-95.

Eriksen, Sidsel, 1991. “Det Andet Stavnsbånd: Et Studie I Thisted Afholdsforenings Ideologi Og Arbejde for at Forandre Mennesker Og Samfund" Jysk Selskab for Historie 18: 529-88.

Esche, Thora, 1920. Erindringer Fra Mit Liv Og Min Gerning. (Copenhagen, Frimodt).

Fleisch, Paul, 1903. Die Moderne Gemeinschaftsbewegung in Deutschland. Ein Versuch, Ddieselbe Nach Ihren Ursprüngen Dazustellen Und Zu Würdigen (Leipzig, H G Wallmann).

Forell, George, 1999. Faith Active in Love (Eugene OR, Wipf \& Stock Publishers).

Go, Julian, 2008. American Empire and the Politics of Meaning: Elite Political Cultures in the Philippines and Puerto Rico during U.S. Colonialism (Durham, Duke University Press).

Gorski, Philip, 1993. "The Protestant Ethic Revisited: Disciplinary Revolution and State Formation in Holland and Prussia", American Journal of Sociology 99 (2): 265-316.

Granum-Jensen, A. R., 1979. Baggrund Og Glimt Fra Blå Kors’ Historie i 100 År (Fredericia, Blå Kors samt eksp. Lohse).

Griffin, Clifford S., 1983. Their Brothers' Keepers: Moral Stewardship in the United States, 18001865 (Westport, Conn, Greenwood Press).

Gundelach, Peter., 1988. Sociale bevægelser og samfundsændringer: nye sociale grupperinger og deres organisationsformer ved overgangen til ændrede samfundstyper (Aarhus, Politica).

Guthrie, Thomas, 2015. The City: Its Sins and Sorrows; Being a Series of Sermons From Luke XIX. 41 (London: Forgotten Books).

Haskell, Thomas L., 1985a. "Capitalism and the Origins of the Humanitarian Sensibility, Part 1" The American Historical Review 90(2): 339.

Haskell, Thomas L., 1985b. "Capitalism and the Origins of the Humanitarian Sensibility, Part 2" The American Historical Review 90(3): 547.

Henriksen, Lars Skov, and Peter Bundesen, 2004. "The Moving Frontier in Denmark: VoluntaryState Relationships since 1850." Journal of Social Policy 33(4): 605-25. 
Protestant Ethics-In-Action

Published in European Journal of Sociology

Holt, Paul, 1940. Nød Dem : Kirkelig Forening for Indre Mission I København Gennem Trekvart Aarhundrede : 1865-1940. (Copenhagen, Kirkelig Forening for Indre Mission i København).

Holt, Paul, 1979. Kirkelig Forening for Den Indre Mission I Danmark Gennem 100 År : 1861-1961. (Copenhagen, Lohse).

Janoski, Thomas, 1998. Citizenship and civil society: a framework of rights and obligations in liberal, traditional, and social democratic regimes (Cambridge, Cambridge Univ. Press).

Janssen, Karl, 1956. "Einführung" in WICHERN, Johann Hinrich, Ausgewählte Schriften, Vol. 1: Schriften Zur Sozialen Frage (Gütersloh, Carl Bertelsmann: 135-45).

Janssen, Karl, and Rudolf Sieverts, 1962. "Einführung" in WICHERN, Johann Hinrich, Ausgewählte Schriften Vol. 3.: Schriften Zur Gefängnisreform; Die Denkschrift (Gütersloh, Carl Bertelsmann: 957).

Joas, Hans, 1999. "Combining Value Pluralism and Moral Universalism: Isaiah Berlin and Beyond", The Responsive Community 9 (4): 17-29.

Joas, Hans, 2000. The Genesis of Values (Chicago, University of Chicago Press).

Joas, Hans, 2013. The Sacredness of the Person: A New Genealogy of Human Rights (Washington, D.C, Georgetown University Press).

Joas, Hans, 2014. Was ist die Achsenzeit? eine wissenschaftliche Debatte als Diskurs über Transzendenz. Jacob-Burckhardt-Gespräche auf Castelen 29 (Basel, Schwabe).

Joas, Hans, and Frank Adloff, 2007. "Transformations of German Civil Society: Milieu Change and Community Spirit." In Civil Society - Berlin Perspectives (New York; Oxford, Berghahn Books).

Joas, Hans, and Jens Beckert, 2006. "Action Theory", in Jonathan H Turner, ed., Handbook of Sociological Theory (Dordrecht, Springer:269-85).

Kahl, Sigrun, 2005. "The Religious Roots of Modern Poverty Policy: Catholic, Lutheran, and Reformed Protestant Traditions Compared", European Journal of Sociology 46 (1): 91.

Kaspersen, Lars Bo, and Johannes Lindvall, 2008. "Why No Religious Politics? The Secularization of Poor Relief and Primary Education in Denmark and Sweden", European Journal of Sociology 49(1).

Kersbergen, Kees van, and Philip Manow, eds., 2009. Religion, Class Coalitions, and Welfare States. Cambridge Studies in Social Theory, Religion, and Politics. (Cambridge; New York, Cambridge University Press). 
Protestant Ethics-In-Action

Published in European Journal of Sociology

Knudsen, Holger, 1984. De Hellige: Erindringer Om de Gudelige Forsamlinger Og Indre Mission Socialhistorisk Set (Aalborg, Aalborg Universitetsforlag).

Knudsen, Tim, ed., 2000. Den Nordiske Protestantisme Og Velfærdsstaten (Aarhus: Aarhus universitetsforlag).

Kofoed, Nina Javette, 2014. "Performing Male Political Citizenship: Local Philanthropy as an Arena for Practicing and Negotiating Citizenship in Late Nineteenth-Century Denmark" in CROWMAN Krista, Nina Javette Kofoed, and Åsa Karlsson Sjögren, eds., Gender in Urban Europe : Sites of Political Activity and Citizenship, 1750-1900 (New York/London, Routledge).

Larsen, Kurt E., 2000. Vilhelm Beck, Kirken Og Den Indre Mission : En Studie I Forholdet Mellem Vækkelsesbevægelse Og Folkekirke 1849-1901 (Aarhus, Det Teologiske Fakultet, Århus Universitet).

Larsen, Kurt E., 2010. "Indre Mission, Socialt Arbejde Og Velfærdssamfundet." In I Himlen Således Også På Jorden? University of Southern Denmark Studies in History and Social Sciences, Vol. 396. Odense: University of Southern Denmark.

Larsen, Kurt E., 2011. En Bevægelse I Bevægelse: Indre Mission I Danmark 1861-2011 (Fredericia, Lohse).

Lichterman, Paul, and Nina Eliasoph, 2014. "Civic Action”, American Journal of Sociology 120 (3): 798-863.

Lieburg, F. A. van, ed., 2012. Opwekking van de Natie: Het Protestantse Réveil in Nederland (Hilversum, Verloren).

Lindhardt, P. G., 1978. Vækkelse og kirkelige retninger (Aarhus, Aros).

Lützen, Karin, 1998. Byen tæmmes: Kernefamilie, sociale reformer og velgørenhed i 1800-tallets København (Copenhagen, Hans Reitzel).

Lützen, Karin, 2002. "Benevolent Societies and Homes in 19th-Century Copenhagen" in JENSEN Henrik, ed., The Welfare State: Past, Present, Future Clioh's Workshop II 4 (Pisa, Edizione Plus).

Malmgart, Liselotte, 2002. "Ingen Skal Gå Sulten I Seng": Samvirkende Menighedsplejer 1902 2002 (Valby, Samvirkende Menighedsplejer).

Malmgart, Liselotte, 2010. "Frivillig Næstekærlighed Og Tvungen Velfærd." in HANSEN Nils Gunder, Jørn Henrik PETERSEN, and Klaus PETERSEN, eds., I Himlen Således Også På Jorden? : Danske Kirkefolk Om Velfærdsstaten Og Det Moderne Samfund (Odense, Syddansk Universitetsforlag: 57-70).

Mann, Michael, 2012. The Sources of Social Power (New York, Cambridge University Press). 
Protestant Ethics-In-Action

Published in European Journal of Sociology

Manow, Philip, 2008. Religion Und Sozialstaat: Die Konfessionellen Grundlagen Europäischer Wohlfahrtsstaatsregime (Frankfurt am Main; New York, Campus).

Markkola, Pirjo, 2010. "The Lutheran Nordic Welfare States" in KETTUNEN Pauli and Klaus PETERSEN, eds., Beyond Welfare State Models: Transnational Historical Perspectives on Social Policy (Cheltenham, Edward Elgar).

Martensen, H., 1874. Socialisme Og Christendom: Et Brudstykke Af Den Specielle Ethik (Copenhagen, Gyldendal).

McGrath, Alister E., 2005. Iustitia Dei: A History of the Christian Doctrine of Justification. 3rd ed. (Cambridge; New York, Cambridge University Press).

McLoughlin, William G., 1978. Revivals, Awakenings, and Reform: An Essay on Religion and Social Change in America, 1607-1977 (Chicago, University of Chicago Press).

Ohlemacher, Jörg. 1986. Das Reich Gottes in Deutschland Bauen : Ein Beitrag Zur Vorgeschichte Und Theologie Der Deutschen Gemeinschaftsbewegung (Göttingen, Vandenhoeck \& Ruprecht).

Olesen, Elith, 1964. "Blev Harald Steins Program Gennemført? Nogle Bemærkninger I Anledning Af København Indre Missions 100 Års Jubilæum”, Årbog (Den Danske Diakonissestiftelse) (Den Danske Diakonissestiftelse: 5-34).

Olesen, Elith, 1983. “Kampen Om Midtjylland.” Århus Stift, 21: 54-78.

Olesen, Elith, 1996. De Frigjorte Og Trællefolket: Amerikansk-Engelsk Indflydelse På Dansk Kirkeliv Omkring År 1900 (Frederiksberg, Forl. ANIS).

Perez-Diaz, V., 2014. “Civil Society: A Multi-Layered Concept”, Current Sociology 62 (6): 812-30.

Putnam, Robert D., 1994. Making Democracy Work: Civic Traditions in Modern Italy (Princeton, NJ, Princeton Univ. Press).

Putnam, Robert D., 1995. "Bowling Alone: America's Declining Social Capital”, Journal of Democracy 6 (1): 65-78.

Putnam, Robert D., 2000. Bowling Alone: The Collapse and Revival of American Community (New York, Simon \& Schuster).

Schram, P. L., 1978. "Wichern Und Heldring in Beziehung Zum Pietismus." in BERG J. van den and J. P. VAN DOOREN, eds., Pietismus Und Reveil : Referate Der Internationalen Tagung, Der Pietismus in Den Niederlanden Und Seine Internationalen Beziehungen, Zeist 18-22. Juni 1974 (Leiden, E. J. Brill: 343-51). 
Protestant Ethics-In-Action

Published in European Journal of Sociology

Sewell, William H., 1992. "A Theory of Structure: Duality, Agency, and Transformation", American Journal of Sociology 98 (1): 1-29.

Shanahan, William Oswald, 1954. German Protestants Face the Social Question; Volume 1, The Conservative Phase, 1815-1871 (Notre Dame, University of Notre Dame Press).

Skinner, Quentin, 2002. "Retrospect: Studying Rhetoric and Conceptual Change", Visions of Politics Vol 1 (Cambridge; New York, Cambridge University Press: 175-87).

Skocpol, Theda, 1997. "The Tocqueville Problem: Civic Engagement in American Democracy", Social Science History 21 (4): 455.

Skocpol, Theda, 2004. Diminished Democracy: From Membership to Management in American Civic Life (Norman, Univ. of Oklahoma Press).

Skocpol, Theda, and Morris P. Fiorina, eds., 1999. Civic Engagement in American Democracy (Washington, D.C., Brookings Institution Press; New York, Russell Sage Foundation).

Smith, Timothy Lawrence, 1976. Revivalism and Social Reform: American Protestantism on the Eve of the Civil War (New York, Harper \& Row).

Sørensen, Aage B., 1998. "On Kings, Pietism and Rent-Seeking in Scandinavian Welfare States" Acta Sociologica 41 (4): 363-75.

Steen, Julius, and Henrik Hoffmeyer, 1915. Kirkelig Forening for Indre Mission I København 18651915 : Festskrift I Anledning Af 50-Aars Dagen for Missionens Stiftelse (Copenhagen, Bethesda).

Steensland, Brian, ed., 2014. The New Evangelical Social Engagement (New York NY, Oxford University Press).

Stein, Harald, 1872. Nogle Blade Af Den Kristne Kvindes Historie (Copenhagen, Delbanco).

Stein, Harald, 1882. Hvad Vil Den Indre Mission? : Otte Foredrag Om Tro, Virksom I Kjærlighed, Holdte I Den Indre Missions Lokale I Kjøbenhavn. 3rd ed. (Copenhagen: Indre Missions Boghandel).

Stein, Johannes, 1933. Biskop Harald Stein (Copenhagen, G E C Gads Forlag).

Swidler, Ann, 1986. "Culture in Action: Symbols and Strategies," American Sociological Review 51 (2): 273-86.

Tawney, Richard Henry, 1972. Religion and the Rise of Capitalism: A Historical Study (Harmondsworth, Penguin Books).

Thompson, Edward Palmer, 1963. The Making of the English Working Class. New ed. (London, Penguin). 
Protestant Ethics-In-Action

Published in European Journal of Sociology

Thomsen, M., 1904. Gaardmissionær R. B. Clausen (Copenhagen, Bethesda).

Tilly, Charles, 1993. "Contentious Repertoires in Great Britain, 1758-1834", Social Science History 17 (2): 253-80.

Tilly, Charles, 2012. Social Movements, 1768-2012 (Boulder, CO, Paradigm Publishers).

Trägårdh, Lars, ed., 2007. State and Civil Society in Northern Europe: The Swedish Model Reconsidered (New York, Berghahn Books).

Van Drenth, Annemieke, 2002. "The City and the Self. The Case of Girls' Protection in the Netherlands around 1900", Educational Review 54 (2): 125-32.

Weber, Max, 1988. Gesammelte Aufsätze zur Religionssoziologie (Tübingen, J.C.B. Mohr (Paul Siebeck)).

Wichern, Johann Hinrich, 1956a. Schriften Zur Sozialen Frage. Ausgewählte Schriften Vol. 1, JANSSEN, Karl, ed., (Gütersloh, Carl Bertelsmann).

Wichern, Johann Hinrich, 1956b. "Die Innere Mission Der Deutschen Evangelischen Kirche. Eine Denkschrift an Die Deutsche Nation" in JANSSEN and Rudolf SIEVERTS, eds., Ausgewählte Schriften (Gütersloh, Carl Bertelsmann).

Young, Michael P., 2002. "Confessional Protest: The Religious Birth of U.S. National Social Movements" American Sociological Review 67 (5): 660-88.

Young, Michael P., 2006. Bearing Witness against Sin: The Evangelical Birth of the American Social Movement (Chicago, University of Chicago Press).

Zaret, David, 1995. "The Use and Abuse of Textual Data" in LEHMANN, Hartmut and Guenther ROTH, eds., Weber's Protestant Ethic: Origins, Evidence, Contexts (Washington, D.C., Cambridge Univ. Press). 